\title{
Identifying social-ecological gaps to promote biocrust conservation actions
}

\author{
María D. López-Rodríguez ${ }^{1}$, Sonia Chamizo ${ }^{2,3}$, Yolanda Cantón ${ }^{2,3}$, and Emilio Rodriguez-Caballero ${ }^{2,3}$ \\ ${ }^{1}$ Internet Interdisciplinary Institute (IN3), Universitat Oberta de Catalunya, Av. Carl Friedrich Gauss, \\ Castelldefels, Barcelona, 08860, Spain \\ ${ }^{2}$ Agronomy Department, University of Almería, Ctra. Sacramento s/n, 04120, Almería, Spain \\ ${ }^{3}$ Centro de Investigación de Colecciones Científicas de la Universidad de Almería (CECOUAL), Almería, Spain
}

Correspondence: María D. López-Rodríguez (mlopezrodrigu@uoc.edu) and Emilio Rodriguez-Caballero (rce959@ual.es)

Received: 12 June 2020 - Revised: 1 August 2020 - Accepted: 13 August 2020 - Published: 23 September 2020

\begin{abstract}
Globally, most bare-looking areas in dryland regions are covered by biocrusts which play a crucial role in modifying several soil surface properties and driving key ecosystem processes. These keystone communities face important threats (e.g. climate change) that place their conservation at risk and in turn the sustainability of the ecosystems they inhabit. Therefore, there is an urgent need to develop ecosystem management strategies to ensure their protection. However, to provide a solid path towards biocrust conservation, the understanding by stakeholders and governance structures of the ecological functions of these communities, their role as benefit providers, and the pressures threatening their important effects are indispensable. Whereas the ecological scope of biocrust has been widely studied in the last decades, the social dimension of their role remained unexplored. By reviewing literature in biocrusts from a social-ecological approach, here we identified knowledge gaps and new research areas that need to be addressed in order to produce scientific knowledge that better guides dryland conservation policies and actions. This research agenda is a prerequisite to advance biocrust conservation.
\end{abstract}

\section{Introduction}

Most open areas in dryland regions around the world are covered by biological soil crusts or "biocrusts" (RodriguezCaballero et al., 2018a), which are poikilohydric communities composed of associations between soil particles and eukaryotic algae, cyanobacteria, lichen, mosses, and liverworts growing together with heterotrophic micro-decomposers in a faunal food web (Bowker et al., 2018). By covering the soil surface, biocrusts play a key role in maintaining arid ecosystems at the global scale, as they promote biodiversity (Bowker et al., 2010a), direct numerous key ecosystem processes (reviewed in Weber et al., 2016), and provide multiple regulating services (Concostrina-Zubiri et al., 2017; Rodriguez-Caballero et al., 2018b). For example, it has been demonstrated that although biocrusts only represent a very thin layer at the soil surface, they regulate soil biogeochemical and water fluxes (Chamizo et al., 2016; Maier et al., 2018) and form a cohesive network that stabilizes soil (Belnap et al., 2014).

Biocrust-forming organisms are well adapted to aridity and survive some of the most extreme environments on Earth (i.e. polar regions or hyperarid deserts). However, they are highly vulnerable to subtle changes in climate conditions and to disturbance derived from human activities (Maestre et al., 2013; Reed et al., 2019). Consequently, global biocrust coverage is expected to decrease dramatically by the end of this century (Rodriguez-Caballero et al., 2018a). In addition, manipulation experiments on different regions revealed that disturbance and climate change will cause the loss of some biocrust constituents such as lichens and mosses, leading to a community shift towards early cyanobacteria dominance. Both biocrust coverage loss and community composition changes are expected to have strong negative impacts on soil biodiversity and on the functioning and resilience of 
dryland landscapes (Maestre et al., 2013; Ladrón de Guevara et al., 2014; Reed et al., 2019).

Given the importance of biocrusts for the sustainability of global drylands and the increasing pressure these communities undergo and that threatens their conservation, there is an urgent need to develop legal frameworks that underpin the protection and conservation of these keystone communities. Scientific evidence obtained from more than 2 decades of intensive research around the world (reviewed in Belnap and Lange, 2003, and Weber et al., 2016) represents a great resource to support the importance of biocrust conservation and the achievement of sustainable biocrust management in dryland ecosystems. However, it is widely recognized that there are barriers between science and governance decisionmaking that hinder translation of the scientific evidence to conservation actions (Ellison, 2016). In an attempt to address this conservation challenge, there are certain voices within the international research community that encourage adopting new research framings focused on producing knowledge able to properly inform policy actions and management practices (Mastrángelo et al., 2019). Within the multiple conservation framings in use today (Mace, 2014), literature increasingly recognizes the social-ecological approach as an adequate scientific means to achieve it (Ban et al., 2013; Díaz et al., 2015; Mastrángelo et al., 2019). The social-ecological approach is based on the paradigm of "people and nature" and emphasizes the importance of institutions and social structures for transitioning towards sustainable interactions between human societies and the natural environment (Mace, 2014). Adopting the so-far underused social-ecological perspective would be a novel approach for biocrust researchers to build new scientific knowledge to address the demanding challenge in drylands which is the conservation of biocrust communities.

The BIOCOST project (http://www2.ual.es/cecoual/ costras-biologicas/, last access: 19 September 2020) aims to deal with the current biocrust conservation challenge by means of facilitating the use of scientific evidence for policy actions and management practices. In order to instigate the project, we selected Spain as a pilot area. Given the extent (about $75 \%$ of the national territory; Martínez-Valderrama et al., 2020) and the whole range of favourable environmental conditions for biocrusts, Spanish drylands are characterized by a great diversity of biocrust-forming organisms that play a crucial role in many ecosystem processes and represent an excellent field laboratory to work with biocrusts (Maestre et al., 2011). Indeed, Spain has become one of the world's biggest spots for biocrust studies (Rodriguez-Caballero et al., 2018a), as reflected in the increasing trend of research groups doing biocrust research over the past decades (Maestre et al., 2011). As a first step to achieve this goal, we conducted a literature review on biocrusts through the lens of a social-ecological approach with the aim of (1) analysing how biocrust research has evolved in Spain, (2) identifying to which extent biocrust research has contributed to different knowledge areas required for supporting biocrust conservation, and (3) elucidating knowledge gaps and new research opportunities for conservation actions.

\section{Conceptual framework}

To develop the study, we used the conceptual framework adopted by the Intergovernmental Platform on Biodiversity and Ecosystem Services (IPBES) (Díaz et al., 2015) (Appendix A, Fig. A1). The IPBES framework is built upon a social-ecological approach and aims at providing a shared language that catalyses the generation of new scientific knowledge for supporting policy formulation and implementation on conservation biodiversity. According to Díaz et al. (2015), the IPBES framework is formed by 16 elements (six categorized components and 10 linkages among them) that represent a social-ecological system that operates at various scales in time and space (Appendix A, Fig. A1). These six components and concepts are (1) nature, "the natural world with an emphasis on biodiversity, ecosystems, ecosystem structure and functioning, the evolutionary process, the biosphere, living natural resources"; (2) nature's contributions to people, "all the benefits that humanity obtains from nature, including ecosystem goods and services"; (3) anthropogenic assets, "highlight that a good life is achieved by a co-production of benefits between nature and various assets built by people, and it refers to built infrastructure, health facilities, knowledge, technology, and financial assets, among others"; (4) institutions and governance systems and other indirect drivers of change, "the ways in which people and societies organize themselves and their interactions with nature at different scales"; (5) direct drivers of change, "natural direct drivers are those that are not the result of human activities and whose occurrence is beyond human control, whereas anthropogenic direct drivers are those that are the result of human decisions and actions"; and (6) good quality of life, "the achievement of a fulfilled human life". The complex interactions among these six components are represented through 10 listed linkages (Appendix A, Fig. A1). This conceptual framing was specifically adapted to the study case of biocrusts to generate a new biocrust-based conceptual framework that accounted for natural, social, and institutional aspects involving biocrust research.

\section{Methodological approach}

To examine biocrust research background generated in Spain, we first conducted a literature review. We used Scopus to identify all papers containing the terms "biocrust", "biological soil crust", and "microphytic crust" in the title, abstract, or keywords. The literature search was conducted on 28 June 2019. We restricted the literature review to articles in English and Spanish. We did not include review papers to avoid duplicate evidence. For each retrieved article, we 
identified authors, year of publication, keywords, and study site. Then, we selected those articles conducted in Spanish regions. We reviewed the full text of the articles and established associations between the generated knowledge in each article and the different elements of the IPBES framework (Appendix A, Fig. A1). Associations were established across the six categorized IPBES components (nature, nature's contributions to people, anthropogenic assets, institutions and governance systems and other indirect drivers of change, direct drivers of change, and good quality of life) if generated knowledge provided further information about them (e.g. a study analysing direct effects of biocrusts in soil stability or biodiversity implied one association with the nature component). Associations with the interactions among the six IPBES components (linkages from 1 to 10 ) were assigned to those studies analysing the influence of any constituents of an IPBES component in any other component. For instance, a study focused on the implications of climate change (direct driver of change component) in biocrust composition (nature component) implied one association with "linkage number 3 ". In doing so, we used a binary scale $(0$, not associated; 1 , associated) according to Mastrángelo et al. (2019). We established as criteria that the scientific knowledge contained in a single article should imply more than one association with the IPBES elements. In addition, we identified whether publications highlight implications for conservation practice. A simple binary option of ones and zeros was used to indicate the existence (or not) of recommendations for guiding management strategies and actions for biocrust conservation.

\section{Results and discussion}

Biocrusts were described in Spain almost 50 years ago (Crespo, 1973; Llimona, 1974; Crespo and Barreno, 1975). However, their ecological functions remained quite uninvestigated until the 1990s (Maestre et al., 2011). It was during the XXI century when biocrust science in Spain experienced an important upsurge, following the global trend described by Bowker et al. (2018) and probably motivated by the first publication of the biocrust book Biological Soil Crusts: Structure, Function and Management (Belnap and Lange, 2003). In this regard, it should be noted that the literature review did not capture the mentioned original studies because the term biological soil crusts was not employed in such studies (i.e. Alexander and Calvo, 1990; Calvo-Cases et al., 1991; Guerra et al., 1995; Canton et al., 2001). From 2000 to 2019, more than 90 peer-reviewed articles analysing biocrust communities within the Spanish regions have been published (Fig. 1). This research represents about $10 \%$ of the total number of biocrust articles published on a global scale during the same period. These numbers position Spain as one of the hot spots of biocrust science, and their relevance would probably increase if we considered that during the last decade many Spanish researchers have been in- volved in international projects and networks that focused their research effort in other regions that were not considered in this review. During the analysis of the identified articles, we established 239 associations between the scientific knowledge generated in each study and the IPBES elements (Appendix B, Table B1). These associations encompassed four of the six main components (nature $n=150$; nature's contributions to people $n=10$; anthropogenic assets $n=18$; good quality of life $n=2$ ) and 2 of the 10 linkages (linkage between direct drivers of change and nature (linkage number 3), $n=49$; linkage between nature and nature's contributions to people (linkage number 4), $n=10$ ) (Fig. 1).

As observed in Fig. 1, the biocrust research community has a strong focus on fundamental natural sciences with most effort aimed at the nature component (150 associations). In particular, biocrusts' structure, composition, and functioning ( $57 \%$ of the total associations within the nature component), their effects on water availability, biogeochemical fluxes and other non-living natural resources $(19 \%)$, and their contribution to ecosystem biodiversity $(18 \%)$ have fuelled most research interests (Fig. 2). Regardless of taxonomic composition, all these studies identified biocrusts as a biodiverse (Concostrina-Zubiri et al., 2014a; Blanco-Sacristan et al., 2019) and multifunctional component of Spanish drylands (Maestre et al., 2011) that controls biogeochemical cycles (i.e. Castillo-Monroy et al., 2010; Maestre et al., 2013; Delgado-Baquerizo et al., 2010; Escolar et al., 2015; Miralles et al., 2018), regulates water availability (i.e. Chamizo et al., 2013a, 2016; Cantón et al., 2020), and protects soil from water erosion (Lazaro et al., 2008; Chamizo et al., 2012c). Some other studies have also evaluated the linkages and interactions between all these positive effects of biocrusts and the performance of other living natural resources $(5 \%)$ such as vascular plants (i.e. Luzuriaga et al., 2012; RodriguezCaballero et al., 2018b) or vertebrates (Eldridge et al., 2010; Fig. 2).

The second IPBES element that most called the attention of biocrust researchers in Spain has been the response of biocrusts to natural and anthropogenic direct drivers of change, which is represented by the linkage between drivers of change and nature or linkage number 3 (49 associations; Fig. 1). Here, the effect of both natural and anthropogenic drivers on biocrusts has been analysed in a similar proportion (Fig. 2). Most of these studies concluded that, in a similar way as observed in other regions of the world (Reed et al., 2019), Spanish biocrusts are also endangered by ongoing climate change and land-use intensification. Predicted temperature increase and changes in precipitation pattern over the Mediterranean basin (IPCC, 2013) will affect the coverage and spatial distribution of biocrust communities and may lead to a community shift from well-developed lichen- and moss-dominated biocrusts to early cyanobacteria (Maestre et al., 2013). This, as well as physical alteration of biocrusts by human activities (i.e. trampling), will reduce their coverage, 


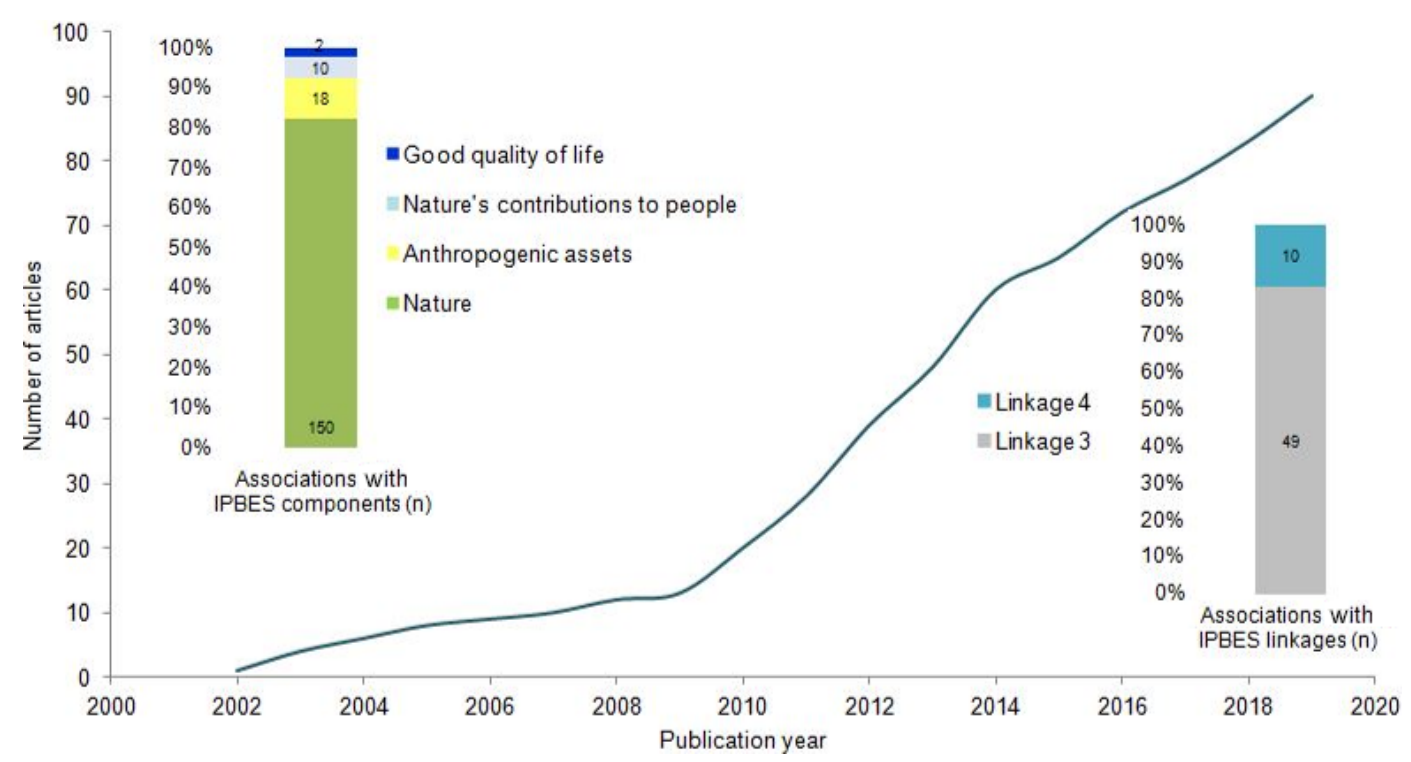

Figure 1. Evolution of the number of articles published regarding biocrust topics in Spain. Bar charts represent the contribution of these publications to the different IPBES components and linkages. Linkage numbers 3 and 4 refer, respectively, to linkage between direct drivers of change and nature and linkage between nature and nature's contributions to people.

biodiversity, and capacity to provide services and benefits to society (Rodriguez-Caballero et al., 2018c).

The notion of ecosystem services has not been very popular within the biocrust community, even though such a notion is hypothesized to represent a powerful communication tool for raising awareness about benefits that society derives from nature (Abson et al., 2014; Kadykalo et al., 2019). Only 10 studies have somehow adopted an ecosystem service perspective, represented by the linkage between nature and nature's contributions to people or linkage number 4 (10 associations; Fig. 1). All of them elucidate the potential benefits of biocrust maintenance for regulating services through processes such as atmospheric $\mathrm{CO} 2$ fixation (i.e. Maestre et al., 2013; Miralles et al., 2018) and other biogeochemical fluxes that affect soil fertility (García-Palacios et al., 2011; Chamizo et al., 2013a), erosion control (RodriguezCaballero et al., 2018c; Chamizo et al., 2012b), or water regulation (i.e. Eldridge et al., 2010; Chamizo et al., 2016; Rodriguez-Caballero et al., 2018c). The rest of the ecosystem service categories (i.e. provisioning and cultural) is still outside the research focus. Ecosystem service studies are hypothesized to be helpful in facilitating understanding of scientific discourse on the benefits of nature to the people (Abson et al., 2014). Thus, the underrepresentation of studies dealing with this topic, in comparison with the number of studies focused on the natural component, may hinder the possibility for biocrusts and their benefits to be known and understood by the policy community and general public. This fact has been indeed confirmed by one recent study that, by incorporating the social perspective in biocrust research, demonstrated the lack of awareness of so- ciety concerning the benefits/ecosystem services provided by biocrusts (Rodriguez-Caballero et al., 2018c). Some reasons that explain such a lack of consciousness concerning the role of biocrusts as providers of ecosystem services to society could be (1) the false perception of drylands as barren lands due to low plant cover and existence of large open areas between plants which are commonly believed to be "devoid of life" and (2) the predominant composition in many biocrust communities of microscopic organisms, not visually evident, which represents an additional obstacle to draw the attention of the general public towards their high representativeness and relevance in drylands. This reinforces the idea that new studies are needed in the ecosystem service field to make evident the benefits provided by biocrusts to people. There is also a demand for quantifying the importance of these keystone communities for the maintenance of human well-being (good quality of life component) in dryland regions, which is an important component of the IPBES framework that has also been largely unaddressed by the researchers (two associations; Fig. 1).

Our literature review also sheds light on an increasing interest of the biocrust community in generating applied knowledge, rather than focusing on empirical natural sciences, as demonstrated by the 18 associations within the anthropogenic assets component (Fig. 1). Applied research efforts have been mainly focused on the development of new biotechnological tools to restore degraded drylands by recovering biocrusts and the services they provide (Ballesteros et al., 2017; Román et al., 2018). Practical methodologies for biocrust mapping, monitoring, and modelling (i.e. Rodriguez-Caballero et al., 2017; Blanco-Sacristan et al., 


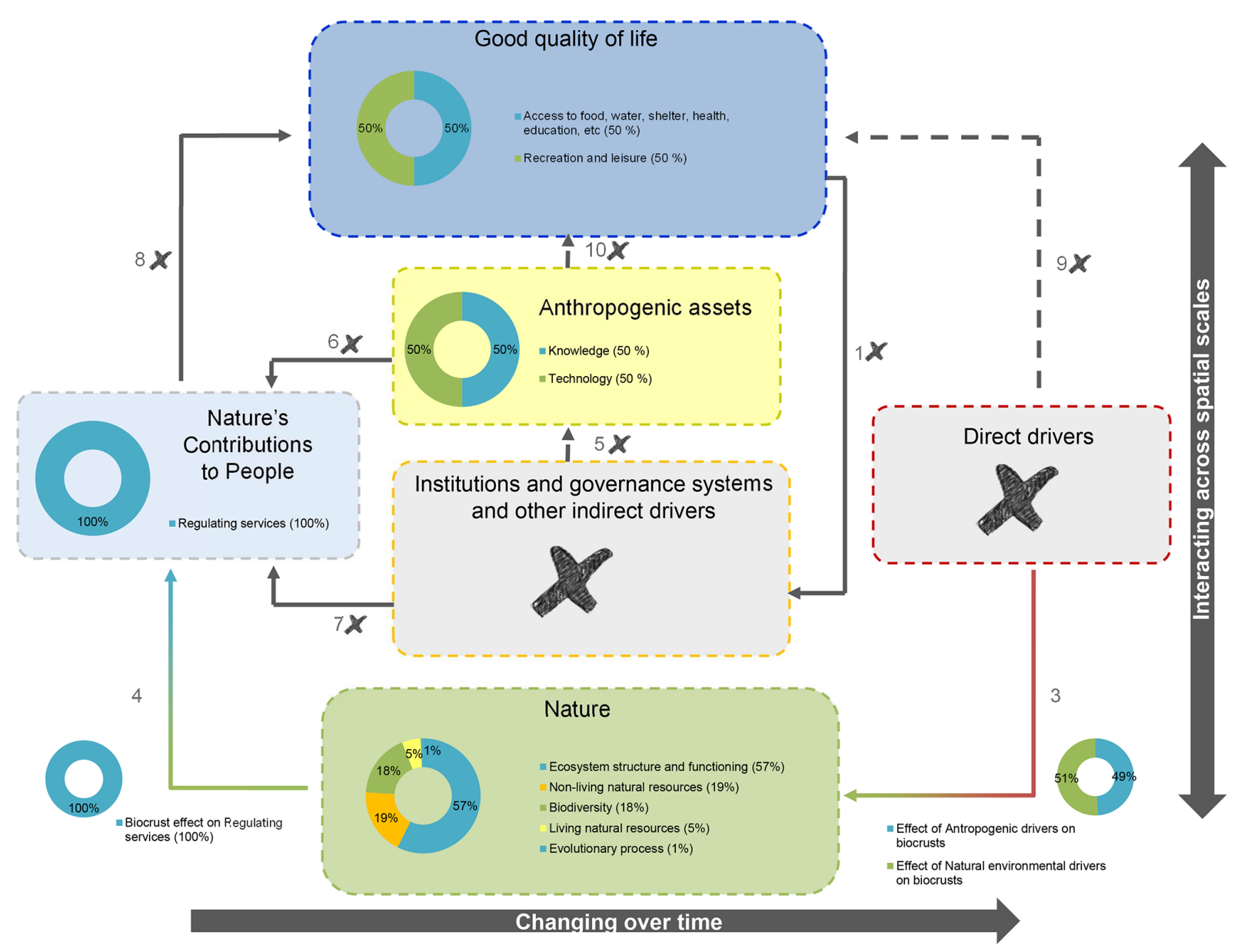

Figure 2. Distribution of biocrust research efforts across the IPBES conceptual framework. Percentage of associations between the knowledge generated in each article and the different elements (six categorized components and 10 linkages among them). The main components are represented by boxes whereas lines represent the linkages among them. The percentage of associations is represented by categories within each element and indicated by the area of the pie chart. Crosses indicate knowledge gaps. Figure adapted from Díaz et al. (2015).

2019; Román et al., 2019) as well as basic knowledge on biocrust ecosystem management that may help land managers to incorporate biocrusts into land-use policies aimed at ensuring drylands sustainability (i.e. Ochoa-Hueso et al., 2011; Rodriguez-Caballero et al., 2015b; Blanco-Sacristan et al., 2019) have also been developed. In addition, we have identified an increasing number of scientists who have begun to be concerned with making recommendations for guiding management strategies and actions for biocrust conservation (11\% of total analysed studies) (Appendix B, Table B1). For example, several researchers recommended considering biocrust presence before disturbance activities, in order to promote best action plans for further recuperation of the native community (Garcia-Palacios et al., 2011; Williams et al., 2017). Others suggested considering biocrust effects on water redistribution processes (Maestre and Cortina, 2002; Rodriguez-Caballero et al., 2018b, 2019) or carbon fluxes (Escolar et al., 2015; Rey et al., 2017).
While there is an increasing concern between scientists for aligning their research with the policy domain, progress in using the scientific knowledge generated for supporting policies and strategies to manage, conserve, and regenerate biocrusts still remains insufficient. There are reasonable grounds to assume the above since legal and institutional frameworks that claim the protection and conservation of biocrusts are absent in Spain, an issue that was already pointed out by Maestre et al. (2011), who brought out the absence of a Spanish red list of endangered biocrusts as evidence of their non-protection. In fact, our review revealed that there are no studies associated with the institutions and governance systems and other indirect drivers component (Fig. 2). This means that we did not find studies specifically focused on facilitating changes in institutional practices and encouraging individual behaviours aimed at protecting biocrusts. Unfortunately, the lack of legal frameworks that protect the conservation of biocrusts appears to go further than Spain and applies also to other countries around 
the world. In an attempt to address this policy-relevant gap, we found that recent initiatives have been launched by the biocrust community in different regions. For example, we can mention the Soil Crust International Project (SCIN, http: //www.biodiversa.org/120, last access: 19 September 2020), whose objective was "to achieve both better appreciation of the functioning and importance of biocrusts in Europe and to add value by contributing to the development of better and simpler soil protection practices and policies". However, we still must push harder in this direction in order to catalyse institutional and social changes for promoting effective biocrust conservation in the short-term.

\section{Conclusions}

This study reveals that scientific knowledge generated on biocrust from an ecological perspective during more than 2 decades of intensive research in Spain has significantly contributed to a fundamental understanding of biocrust structure and functions and the ecological relevance of the ecosystems where they live. In this period, we also found that there was an increasing concern among scientists for aligning their research with conservation strategies to manage and restore biocrusts as well as for emphasizing the benefits that society obtains from them. However, studies focusing on strengthening the connection of biocrust research with policy domain and institutional practices still remain insufficient. This underpins the need to tackle the social dimension of the biocrust role. Therefore, it is timely to reflect on the biocrust research background and on the development of future directions of this burgeoning field of science to promote policy actions and management strategies with a special focus on biocrust conservation. On this basis, we call for a transition from an "ecological research perspective" to a "social-ecological research perspective" into the biocrust area, if advancing towards the implementation of biocrusts' conservation strategies is the goal. The adoption of the "social-ecological research perspective" is needed to (1) produce research that better informs policy and society about the role of these keystone communities and (2) promote the best available evidence on the biocrusts role which can be used to support conservation actions. To deal with this novel research approach, it is necessary for biocrust science to adopt inter- and transdisciplinary work schemes that facilitate collaborative work between scientists from a range of disciplines (e.g. ecology, sociology, and economic sciences) and non-scientist actors related to representative biocrust areas (e.g. practitioners, environmental advocates). These work schemes will allow us to create communities of practice representing science, policy, and society which will work together to promote evidence-based conservation practices on biocrusts and build new road maps that contribute to the preservation of these dryland representative communities from regional to global scales around the world. To move forward in this subject, further studies are needed across countries and regions to build a ranking scheme based on both failures and achievements related to the incorporation of biocrust evidence into conservation policies. 


\section{Appendix A: IPBES framework}

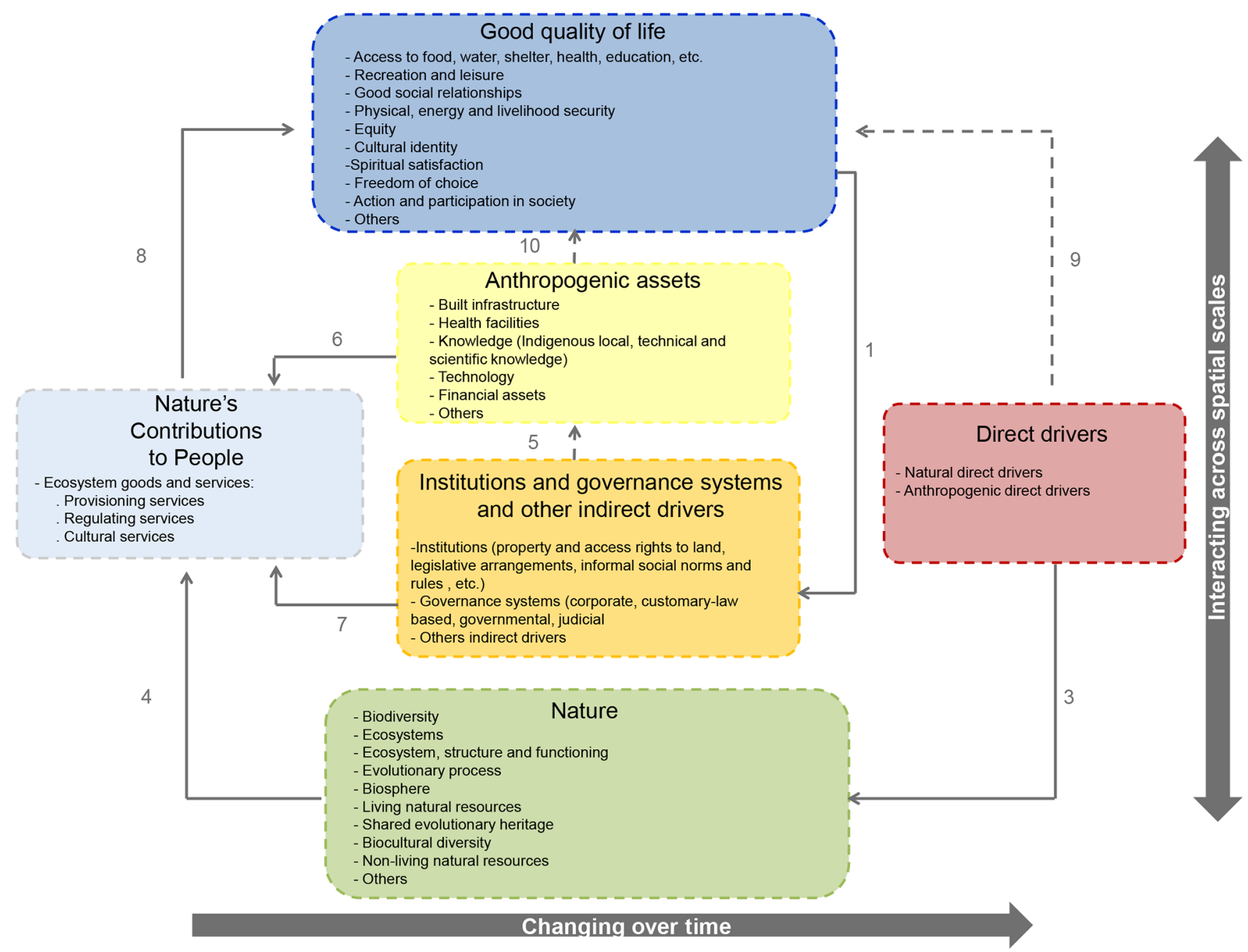

Figure A1. The IPBES framework guiding this research (reproduced from Díaz et al., 2015). Boxes denote six components (nature, nature's contributions to people, anthropogenic assets, institutions and governance systems and other indirect drivers of change, direct drivers of change and good quality of life) and categories within each one. Arrows from 1 to 10 represent the linkages among the six components across different temporal and spatial scales. 
Appendix B: Associations of biocrust knowledge across the IPBES framework and identified

implications for conservation practice

Table B1. List of references on biocrust research analysed in the study and identified associations in four of the six IPBES components (nature, nature's contributions to people, anthropogenic assets, and good quality of life) and 2 of the 10 linkages ("linkage number 3 " (linkage between direct drivers of change and nature) and "linkage number 4" (linkage between nature and nature's contributions to people)). Those IPBES elements for which no associations were identified are not included in the table. Identified implications for conservation practice in references are also shown. Full references can be found at the end of the paper.

\begin{tabular}{|c|c|c|c|c|c|c|c|c|}
\hline \multirow[b]{2}{*}{ ID } & \multirow[b]{2}{*}{$\begin{array}{l}\text { References on } \\
\text { biocrust research } \\
\text { analysed in the study }\end{array}$} & \multicolumn{4}{|c|}{ Identified associations with IPBES components $(n)$} & \multicolumn{2}{|c|}{$\begin{array}{l}\text { Identified associations } \\
\text { IPBES linkages }(n)\end{array}$} & \multirow{2}{*}{$\begin{array}{c}\text { Identified } \\
\text { implications } \\
\text { for } \\
\text { conservation } \\
\text { practice }\end{array}$} \\
\hline & & Nature & $\begin{array}{l}\text { Nature's } \\
\text { contributions } \\
\text { to people }\end{array}$ & $\begin{array}{l}\text { Anthropogenic } \\
\text { assets }\end{array}$ & $\begin{array}{l}\text { Good } \\
\text { quality } \\
\text { of life }\end{array}$ & Linkage 3 & Linkage 4 & \\
\hline 1 & Maestre and Cortina (2002) & 1 & 0 & 0 & 0 & 0 & 0 & 1 \\
\hline 2 & Maestre and Cortina (2003) & 1 & 0 & 0 & 0 & 1 & 0 & 0 \\
\hline 3 & Maestre (2003a) & 1 & 0 & 0 & 0 & 0 & 0 & 0 \\
\hline 4 & Maestre (2003b) & 1 & 0 & 0 & 0 & 0 & 0 & 0 \\
\hline 5 & Cantón et al. (2004) & 1 & 0 & 0 & 0 & 1 & 0 & 0 \\
\hline 6 & Souza-Egipsy et al. (2004) & 1 & 0 & 0 & 0 & 0 & 0 & 0 \\
\hline 7 & Maestre et al. (2005) & 2 & 0 & 0 & 0 & 0 & 0 & 0 \\
\hline 8 & Pintado et al. (2005) & 1 & 0 & 0 & 0 & 1 & 0 & 0 \\
\hline 9 & Martínez et al. (2006) & 2 & 0 & 0 & 0 & 1 & 0 & 0 \\
\hline 10 & Escudero et al. (2007) & 2 & 0 & 1 & 0 & 0 & 0 & 0 \\
\hline 11 & Lázaro et al. (2008) & 2 & 0 & 0 & 0 & 1 & 0 & 0 \\
\hline 12 & Maestre et al. (2008) & 2 & 0 & 0 & 0 & 0 & 0 & 0 \\
\hline 14 & Maestre et al. (2009) & 2 & 0 & 0 & 0 & 1 & 0 & 0 \\
\hline 15 & Bowker et al. (2010b) & 2 & 0 & 0 & 0 & 1 & 0 & 0 \\
\hline 16 & Castillo-Monroy et al. (2010) & 2 & 0 & 0 & 0 & 1 & 0 & 0 \\
\hline 17 & Chamizo et al. (2010) & 2 & 0 & 0 & 0 & 0 & 0 & 0 \\
\hline 18 & Cortina et al. (2010) & 1 & 0 & 0 & 0 & 1 & 0 & 0 \\
\hline 13 & $\begin{array}{l}\text { Delgado-Baquerizo et al. } \\
(2010)\end{array}$ & 2 & 0 & 0 & 0 & 0 & 0 & 0 \\
\hline 19 & Eldridge et al. (2010) & 2 & 1 & 0 & 0 & 0 & 1 & 0 \\
\hline 20 & Maestre et al. (2010) & 2 & 0 & 0 & 0 & 1 & 0 & 0 \\
\hline 21 & Bowker et al. (2011) & 3 & 0 & 0 & 0 & 0 & 0 & 0 \\
\hline 22 & $\begin{array}{l}\text { Castillo-Monroy et al. } \\
\text { (2011a) }\end{array}$ & 2 & 0 & 0 & 0 & 0 & 0 & 0 \\
\hline 23 & $\begin{array}{l}\text { Castillo-Monroy et al. } \\
\text { (2011b) }\end{array}$ & 1 & 1 & 0 & 0 & 0 & 1 & 0 \\
\hline 24 & García-Palacios et al. (2011) & 2 & 1 & 0 & 0 & 1 & 1 & 1 \\
\hline 25 & Gotelli et al. (2011) & 2 & 0 & 1 & 0 & 0 & 0 & 0 \\
\hline 26 & $\begin{array}{l}\text { Miralles-Mellado et al. } \\
\text { (2011) }\end{array}$ & 2 & 0 & 0 & 0 & 0 & 0 & 0 \\
\hline 27 & $\begin{array}{l}\text { Ochoa-Hueso and Manrique } \\
\text { (2011) }\end{array}$ & 1 & 0 & 1 & 0 & 1 & 0 & 0 \\
\hline 28 & Ochoa-Hueso et al. (2011) & 1 & 0 & 1 & 0 & 1 & 0 & 0 \\
\hline 29 & Bowker and Maestre (2012) & 1 & 0 & 0 & 0 & 1 & 0 & 0 \\
\hline 30 & Chamizo et al. (2012a) & 2 & 0 & 0 & 0 & 1 & 0 & 0 \\
\hline 31 & Chamizo et al. (2012b) & 1 & 0 & 1 & 0 & 0 & 0 & 0 \\
\hline 32 & Chamizo et al. (2012c) & 2 & 0 & 0 & 0 & 1 & 0 & 0 \\
\hline 33 & Chamizo et al. (2012d) & 2 & 1 & 0 & 0 & 0 & 1 & 0 \\
\hline 34 & Escolar et al. (2012) & 2 & 0 & 0 & 0 & 1 & 0 & 0 \\
\hline 35 & Luzuriaga et al. (2012) & 3 & 0 & 0 & 0 & 1 & 0 & 0 \\
\hline
\end{tabular}


Table B1. Continued.

\begin{tabular}{|c|c|c|c|c|c|c|c|c|}
\hline \multirow[b]{2}{*}{ ID } & \multirow[b]{2}{*}{$\begin{array}{l}\text { References on } \\
\text { biocrust research } \\
\text { analysed in the study }\end{array}$} & \multicolumn{4}{|c|}{ Identified associations with IPBES components $(n)$} & \multicolumn{2}{|c|}{$\begin{array}{l}\text { Identified associations } \\
\text { IPBES linkages }(n)\end{array}$} & \multirow{2}{*}{$\begin{array}{c}\text { Identified } \\
\text { implications } \\
\text { for } \\
\text { conservation } \\
\text { practice }\end{array}$} \\
\hline & & Nature & $\begin{array}{l}\text { Nature's } \\
\text { contributions } \\
\text { to people }\end{array}$ & $\begin{array}{l}\text { Anthropogenic } \\
\text { assets }\end{array}$ & $\begin{array}{l}\text { Good } \\
\text { quality } \\
\text { of life }\end{array}$ & Linkage 3 & Linkage 4 & \\
\hline 36 & $\begin{array}{l}\text { Miralles et al. } \\
(2012 a)\end{array}$ & 2 & 0 & 0 & 0 & 0 & 0 & 0 \\
\hline 37 & $\begin{array}{l}\text { Miralles et al. } \\
(2012 b)\end{array}$ & 1 & 0 & 0 & 0 & 0 & 0 & 0 \\
\hline 38 & $\begin{array}{l}\text { Miralles et al. } \\
(2012 \mathrm{c})\end{array}$ & 1 & 0 & 0 & 0 & 0 & 0 & 0 \\
\hline 39 & $\begin{array}{l}\text { Rodriguez-Caballero et al. } \\
\text { (2012) }\end{array}$ & 2 & 0 & 0 & 0 & 1 & 0 & 0 \\
\hline 40 & Bowker et al. (2013) & 2 & 0 & 0 & 0 & 1 & 0 & 0 \\
\hline 41 & Chamizo et al. (2013a) & 2 & 0 & 0 & 0 & 1 & 0 & 0 \\
\hline 42 & Chamizo et al. (2013b) & 2 & 1 & 0 & 0 & 1 & 1 & 0 \\
\hline 43 & $\begin{array}{l}\text { Delgado-Baquerizo et al. } \\
\text { (2013a) }\end{array}$ & 2 & 0 & 0 & 0 & 0 & 0 & 0 \\
\hline 44 & $\begin{array}{l}\text { Delgado-Baquerizo et al. } \\
(2013 b)\end{array}$ & 2 & 0 & 0 & 0 & 1 & 0 & 0 \\
\hline 45 & $\begin{array}{l}\text { Delgado-Baquerizo et al. } \\
\text { (2013c) }\end{array}$ & 2 & 0 & 0 & 0 & 0 & 0 & 0 \\
\hline 46 & Maestre et al. (2013) & 2 & 1 & 0 & 0 & 1 & 1 & 0 \\
\hline 47 & $\begin{array}{l}\text { Miralles et al. } \\
\text { (2013) }\end{array}$ & 2 & 0 & 0 & 0 & 0 & 0 & 0 \\
\hline 48 & $\begin{array}{l}\text { Rodriguez-Caballero et al. } \\
\text { (2013) }\end{array}$ & 2 & 1 & 1 & 0 & 1 & 1 & 0 \\
\hline 49 & Bastida et al. (2014) & 3 & 0 & 0 & 0 & 0 & 0 & 0 \\
\hline 50 & Berdugo et al. (2014) & 2 & 0 & 0 & 0 & 0 & 0 & 0 \\
\hline 51 & Büdel et al. (2014) & 3 & 0 & 0 & 0 & 1 & 0 & 1 \\
\hline 52 & $\begin{array}{l}\text { Concostrina-Zubiri et al. } \\
(2014 a)\end{array}$ & 2 & 0 & 0 & 0 & 1 & 0 & 0 \\
\hline 53 & $\begin{array}{l}\text { Concostrina-Zubiri et al. } \\
\text { (2014b) }\end{array}$ & 1 & 0 & 0 & 0 & 1 & 0 & 0 \\
\hline 55 & $\begin{array}{l}\text { Ladrón de Guevara et al. } \\
\text { (2014) }\end{array}$ & 1 & 0 & 0 & 0 & 1 & 0 & 0 \\
\hline 56 & Maier et al. (2014) & 2 & 0 & 0 & 0 & 0 & 0 & 0 \\
\hline 57 & $\begin{array}{l}\text { Mendoza-Aguilar et al. } \\
\text { (2014) }\end{array}$ & 1 & 0 & 0 & 0 & 0 & 0 & 0 \\
\hline 58 & $\begin{array}{l}\text { Miralles et al. } \\
(2014)\end{array}$ & 1 & 0 & 0 & 0 & 1 & 0 & 0 \\
\hline 59 & Raggio et al. (2014) & 1 & 0 & 0 & 0 & 1 & 0 & 0 \\
\hline 60 & $\begin{array}{l}\text { Rodriguez-Caballero et al. } \\
\text { (2014a) }\end{array}$ & 2 & 0 & 0 & 0 & 0 & 0 & 0 \\
\hline 61 & $\begin{array}{l}\text { Rodriguez-Caballero et al. } \\
\text { (2014b) }\end{array}$ & 1 & 0 & 0 & 0 & 0 & 0 & 1 \\
\hline 54 & Escolar et al. (2015) & 1 & 0 & 0 & 0 & 1 & 0 & 0 \\
\hline 63 & $\begin{array}{l}\text { Ladrón de Guevara et al. } \\
\text { (2015) }\end{array}$ & 1 & 0 & 1 & 0 & 0 & 0 & 0 \\
\hline
\end{tabular}


Table B1. Continued.

\begin{tabular}{|c|c|c|c|c|c|c|c|c|}
\hline \multirow[b]{2}{*}{ ID } & \multirow[b]{2}{*}{$\begin{array}{l}\text { References on } \\
\text { biocrust research } \\
\text { analysed in the study }\end{array}$} & \multicolumn{4}{|c|}{ Identified associations with IPBES components $(n)$} & \multicolumn{2}{|c|}{$\begin{array}{l}\text { Identified associations } \\
\text { IPBES linkages }(n)\end{array}$} & \multirow{2}{*}{$\begin{array}{c}\text { Identified } \\
\text { implications } \\
\text { for } \\
\text { conservation } \\
\text { practice }\end{array}$} \\
\hline & & Nature & $\begin{array}{l}\text { Nature's } \\
\text { contributions } \\
\text { to people }\end{array}$ & $\begin{array}{l}\text { Anthropogenic } \\
\text { assets }\end{array}$ & $\begin{array}{l}\text { Good } \\
\text { quality } \\
\text { of life }\end{array}$ & Linkage 3 & Linkage 4 & \\
\hline 64 & $\begin{array}{l}\text { Rodriguez-Caballero et al. } \\
\text { (2015a) }\end{array}$ & 1 & 0 & 0 & 0 & 0 & 0 & 0 \\
\hline 65 & $\begin{array}{l}\text { Rodriguez-Caballero et al. } \\
(2015 b)\end{array}$ & 2 & 0 & 1 & 0 & 0 & 0 & 1 \\
\hline 66 & Chamizo et al. (2016) & 2 & 0 & 0 & 0 & 0 & 0 & 0 \\
\hline 62 & $\begin{array}{l}\text { Delgado-Baquerizo et al. } \\
(2016)\end{array}$ & 2 & 0 & 0 & 0 & 1 & 0 & 0 \\
\hline 68 & Ochoa-Hueso et al. (2016) & 3 & 0 & 0 & 0 & 1 & 0 & 0 \\
\hline 70 & Uclés et al. (2016) & 2 & 0 & 0 & 0 & 0 & 0 & 0 \\
\hline 71 & Williams et al. (2016) & 2 & 0 & 0 & 0 & 1 & 0 & 0 \\
\hline 72 & Ballesteros et al. (2017) & 1 & 0 & 2 & 0 & 1 & 0 & 1 \\
\hline 67 & Chamizo et al. (2017) & 2 & 1 & 0 & 0 & 1 & 1 & 0 \\
\hline 74 & Ochoa-Hueso et al. (2017) & 1 & 0 & 0 & 0 & 1 & 0 & 0 \\
\hline 75 & Raggio et al. (2017) & 1 & 0 & 0 & 0 & 1 & 0 & 1 \\
\hline 69 & Rey et al. (2017) & 2 & 1 & 0 & 0 & 1 & 1 & 0 \\
\hline 76 & $\begin{array}{l}\text { Rodriguez-Caballero et al. } \\
\text { (2017) }\end{array}$ & 1 & 0 & 1 & 0 & 0 & 0 & 0 \\
\hline 77 & Williams et al. (2017) & 2 & 0 & 0 & 0 & 1 & 0 & 0 \\
\hline 78 & Cano-Díaz et al. (2018) & 2 & 0 & 0 & 0 & 0 & 0 & 0 \\
\hline 79 & $\begin{array}{l}\text { Concostrina-Zubiri et al. } \\
\text { (2018) }\end{array}$ & 2 & 0 & 0 & 0 & 1 & 0 & 0 \\
\hline 73 & Lafuente et al. (2018) & 2 & 0 & 0 & 0 & 1 & 0 & 0 \\
\hline 80 & Miralles et al. (2018) & 1 & 0 & 0 & 0 & 1 & 0 & 0 \\
\hline 81 & $\begin{array}{l}\text { Rodriguez-Caballero et al. } \\
(2018 b)\end{array}$ & 2 & 0 & 0 & 0 & 0 & 0 & 0 \\
\hline 82 & $\begin{array}{l}\text { Rodriguez-Caballero et al. } \\
(2018 \mathrm{c})\end{array}$ & 1 & 1 & 0 & 2 & 0 & 1 & 1 \\
\hline 83 & Williams et al. (2018) & 2 & 0 & 1 & 0 & 1 & 0 & 1 \\
\hline 84 & $\begin{array}{l}\text { Blanco-Sacristán et al. } \\
\text { (2019) }\end{array}$ & 1 & 0 & 2 & 0 & 0 & 0 & 0 \\
\hline 85 & $\begin{array}{l}\text { Concostrina-Zubiri et al. } \\
\text { (2019) }\end{array}$ & 2 & 0 & 0 & 0 & 1 & 0 & 0 \\
\hline 86 & Lorite et al. (2019) & 2 & 0 & 0 & 0 & 1 & 0 & 1 \\
\hline 87 & $\begin{array}{l}\text { Rodriguez-Caballero et al. } \\
\text { (2019) }\end{array}$ & 1 & 0 & 0 & 0 & 1 & 0 & 0 \\
\hline 88 & Roman et al. (2019) & 0 & 0 & 2 & 0 & 0 & 0 & 0 \\
\hline 89 & $\begin{array}{l}\text { Roncero-Ramos et al. } \\
\text { (2019a) }\end{array}$ & 0 & 0 & 2 & 0 & 1 & 0 & 0 \\
\hline 90 & $\begin{array}{l}\text { Roncero-Ramos et al. } \\
(2019 b)\end{array}$ & 3 & 0 & 0 & 0 & 0 & 0 & 0 \\
\hline Tota & & 150 & 10 & 18 & 2 & 49 & 10 & 10 \\
\hline
\end{tabular}


Data availability. No data sets were used in this article.

Author contributions. MDLR and ERC conceived and conceptualized the study. ERC conducted the bibliographic search. MDLR and ERC jointly analysed data, designed the manuscript, and wrote the original draft of the manuscript. SC and YC wrote and edited the manuscript. All authors revised and approved the final version of the manuscript.

Competing interests. The authors declare that they have no conflict of interest.

Special issue statement. This article is part of the special issue "Biological soil crusts". It is not associated with a conference.

Acknowledgements. We are very grateful to EEZA, CECOUAL, and CAESCG for providing support for the BIOCOST project. Special thanks to David Eldridge and Diogo Alagador for their insightful and constructive comments raised during the peer review process.

Financial support. This research has been supported by the Biodiversity Foundation of the Ministry for the Ecological Transition (Spain) (BIOCOST project), the REBIOARID (RTI2018-101921B-100) project founded by the Spanish National Plan for Research and cofounded by the European Regional Development Founds, and the Plan Propio de Investigación de la Universida de Almería (HIPATIA-UAL, Emilio Rodriguez-Caballero and Sonia Chamizo).

Review statement. This paper was edited by Laura ConcostrinaZubiri and reviewed by Diogo Alagador and David Eldridge.

\section{References}

Abson, D. J., von Wehrden, H., Baumgaertner, S., Fischer, J., Hanspach, J., Haerdtle, W., Heinrichs, H., Klein, A. M., Lang, D. J., Martens, P., and Walmsley, D.: Ecosystem services as a boundary object for sustainability, Ecol. Econ., 103, 29-37, https://doi.org/10.1016/j.ecolecon.2014.04.012, 2014.

Alexander, R. W. and Calvo, A.: The influence of lichens on slope processes in someSpanish badlands, in: Vegetation and Erosion, edited by: Thornes, J. B., John Wiley \& Sons, Ltd. Chichester, England, 385-398, 1990.

Ballesteros, M., Ayerbe, J., Casares, M., Cañadas, E. M., and Lorite, J.: Successful lichen translocation on disturbed gypsum areas: A test with adhesives to promote the recovery of biological soil crusts, Sci. Rep., 7, 1-9, https://doi.org/10.1038/srep45606, 2017

Ban, N. C., Mills, M., Tam, J., Hicks, C. C., Klain, S., Stoeckl, N., Bottrill, M. C., Levine, J., Pressey, R. L., Satterfield, T., and Chan, K. M. A.: A social-ecological approach to conservation planning: Embedding social considerations, Front. Ecol. Environ., 11, 194-202, https://doi.org/10.1890/110205, 2013.

Bastida, F., Jehmlich, N., Ondoño, S., von Bergen, M., García, C. and Moreno, J. L.: Characterization of the microbial community in biological soil crusts dominated by Fulgensia desertorum (Tomin) Poel., and Squamarina cartilaginea (With.) P. Jame., and in the underlying soil, Soil Biol. Biochem., 76, 7079, https://doi.org/10.1016/j.soilbio.2014.05.004, 2014.

Belnap, J. and Lange, O. L.: Biological Soil Crusts: Structure, Function., and Management, in: Ecological Studies Series 150, edited by: Baldwin, I. T., Caldwell, M. M., Heldmaier, G., Lange, O. L., Mooney, H. A., Schulze, E.- D., and Sommer, U., Springer, 150, p. 503, 2003.

Belnap, J., Walker, B. J., Munson, S. M., and Gill, R. A.: Controls on sediment production in two U.S. deserts, Aeolian Res., 14, 15-24, https://doi.org/10.1016/j.aeolia.2014.03.007, 2014.

Berdugo, M., Soliveres, S., and Maestre, F. T.: Vascular Plant., and Biocrusts Modulate How Abiotic Factors Affect Wettin., and Drying Events in Drylands, Ecosystems, 17, 1242-1256, https://doi.org/10.1007/s10021-014-9790-4, 2014.

Blanco-Sacristán, J., Panigada, C., Tagliabue, G., Gentili, R., Colombo, R., de Guevara, M. L., Maestre, F. T., and Rossini, M.: Spectral diversity successfully estimates the $\alpha$ diversity of biocrust-forming lichens, Remote Sens., 11, 1-16, https://doi.org/10.3390/rs11242942, 2019.

Bowker, M. A. and Maestre, F. T.: Inferring local competition intensity from patch size distributions: A test using biological soil crusts, Oikos, 121, 1914-1922, https://doi.org/10.1111/j.16000706.2012.20192.x, 2012.

Bowker, M. A., Maestre, F. T., and Escolar, C.: Biological crusts as a model system for examining the biodiversity-ecosystem function relationship in soils, Soil Biol. Biochem., 42, 405-417, https://doi.org/10.1016/j.soilbio.2009.10.025, 2010a.

Bowker, M. A., Soliveres, S., and Maestre, F. T.: Competition increases with abiotic stres., and regulates the diversity of biological soil crusts, J. Ecol., 98, 551-560, https://doi.org/10.1111/j.1365-2745.2010.01647.x, 2010b.

Bowker, M. A., Mau, R. L., Maestre, F. T., Escolar, C., and CastilloMonroy, A. P.: Functional profiles reveal unique ecological roles of various biological soil crust organisms, Funct. Ecol., 25, 787795, https://doi.org/10.1111/j.1365-2435.2011.01835.x, 2011.

Bowker, M. A., Eldridge, D. J., Val, J., and Soliveres, S.: Hydrology in a patterned landscape is co-engineered by soil-disturbing animal., and biological crusts, Soil Biol. Biochem., 61, 14-22, https://doi.org/10.1016/j.soilbio.2013.02.002, 2013.

Bowker, M. A., Reed, S. C., Maestre, F. T., and Eldridge, D. J.: Biocrusts: the living skin of the earth, Plant Soil, 429, 1-7, https://doi.org/10.1007/s11104-018-3735-1, 2018.

Büdel, B., Colesie, C., Green, T. G. A., Grube, M., Lázaro Suau, R., Loewen-Schneider, K., Maier, S., Peer, T., Pintado, A., Raggio, J., Ruprecht, U., Sancho, L. G., Schroeter, B., Türk, R., Weber, B., Wedin, M., Westberg, M., Williams, L., and Zheng, L.: Improved appreciation of the functionin., and importance of biological soil crusts in Europe: The Soil Crust International Project (SCIN), Biodivers. Conserv., 23, 1639-1658, https://doi.org/10.1007/s10531-014-0645-2, 2014.

Calvo-Cases, A., Harvey, A. M., Paya-Serrano, J., and Alexander, R. W.: Response of badlands surfaces in South East Spain to simulated rainfall Cuaternario y Geomorfología, 5, 3-14, 1991. 
Cano-Díaz, C., Mateo, P., Muñoz-Martín, M. Á., and Maestre, F. T.: Diversity of biocrust-forming cyanobacteria in a semiarid gypsiferous site from Central Spain, J. Arid Environ., 151, 83-89, https://doi.org/10.1016/j.jaridenv.2017.11.008, 2018.

Cantón, Y., Domingo, F., Solé-Benet, A., and Puigdefábregas, J.: Hydrologica., and erosion response of a badlands system in semiarid SE Spain, J. Hydrology, 252, 65-84, 2001.

Cantón, Y., Del Barrio, G., Solé-Benet, A., and Lázaro, R.: Topographic controls on the spatial distribution of ground cover in the Tabernas badlands of SE Spain, Catena, 55, 341-365, https://doi.org/10.1016/S0341-816200108-5, 2004.

Cantón, Y., Chamizo, S., Rodriguez-Caballero, E., Lázaro, R., Roncero-Ramos, B., Román, J. R., and Solé-Benet, A.: Water regulation in cyanobacterial biocrusts from drylands: negative impacts of anthropogenic disturbance, Water, 12, 720, https://doi.org/10.3390/w12030720, 2020.

Castillo-Monroy, A. P., Maestre, F. T., Delgado-Baquerizo, M., and Gallardo, A.: Biological soil crusts modulate nitrogen availability in semi-arid ecosystems: Insights from a Mediterranean grassland, Plant Soil, 333, 21-34, https://doi.org/10.1007/s11104009-0276-7, 2010.

Castillo-Monroy, A. P., Bowker, M. A., Maestre, F. T., RodríguezEcheverría, S., Martinez, I., Barraza-Zepeda, C. E., and Escolar, C.: Relationships between biological soil crusts, bacterial diversit., and abundance., and ecosystem functioning: Insights from a semi-arid Mediterranean environment, J. Veg. Sci., 22, 165-174, https://doi.org/10.1111/j.1654-1103.2010.01236.x, 2011a.

Castillo-Monroy, A. P., Maestre, F. T., Rey, A., Soliveres, S., and García-Palacios, P.: Biological Soil Crust Microsites Are the Main Contributor to Soil Respiration in a Semiarid Ecosystem, Ecosystems, 14, 835-847, https://doi.org/10.1007/s10021-0119449-3, 2011 b.

Chamizo, S., Rodríguez-Caballero, E., Miralles-Mellado, I., Afana, A., Lázaro, R., Domingo, F., Calvo-Cases, A., Sole-Benet, A., and Cantón, Y.: Características de las costras físicas y biológicas del suelo con mayor influencia sobre la infiltración y la erosión en ecosistemas semiáridos, Pirineos, 165, 69-96, https://doi.org/10.3989/Pirineos.2010.165004, 2010.

Chamizo, S., Cantón, Y., Rodríguez-Caballero, E., Domingo, F., and Escudero, A.: Runoff at contrasting scales in a semiarid ecosystem: A complex balance between biological soil crust feature, and rainfall characteristics, J. Hydrol., 452-453, 130-138, https://doi.org/10.1016/j.jhydrol.2012.05.045, 2012a.

Chamizo, S., Stevens, A., Cantón, Y., Miralles, I., Domingo, F., and Van Wesemael, B.: Discriminating soil crust type, development stag., and degree of disturbance in semiarid environments from their spectral characteristics, Eur. J. Soil Sci., 63, 42-53, https://doi.org/10.1111/j.1365-2389.2011.01406.x, 2012b.

Chamizo, S., Cantón, Y., Lázaro, R., Solé-Benet, A., and Domingo, F.: Crust Compositio., and Disturbance Drive Infiltration Through Biological Soil Crusts in Semiarid Ecosystems, Ecosystems, 15, 148-161, https://doi.org/10.1007/s10021-0119499-6, 2012c.

Chamizo, S., Cantón, Y., Miralles, I., and Domingo, F.: Biological soil crust development affects physicochemical characteristics of soil surface in semiarid ecosystems, Soil Biol. Biochem., 49, 96105, https://doi.org/10.1016/j.soilbio.2012.02.017, 2012d.

Chamizo, S., Cantón, Y., Domingo, F., and Belnap, J.: Evaporative losses from soils covered by physica., and different types of biological soil crusts, Hydrol. Process., 27, 324-332, https://doi.org/10.1002/hyp.8421, 2013a.

Chamizo, S., Cantón, Y., Lázaro, R., and Domingo, F.: The role of biological soil crusts in soil moisture dynamics in two semiarid ecosystems with contrasting soil textures, J. Hydrol., 489, 74-84, https://doi.org/10.1016/j.jhydrol.2013.02.051, 2013b.

Chamizo, S., Cantón, Y., Rodríguez-Caballero, E., and Domingo, F.: Biocrusts positively affect the soil water balance in semiarid ecosystems, Ecohydrology, 9, 1208-1221, https://doi.org/10.1002/eco.1719, 2016.

Chamizo, S., Rodríguez-Caballero, E., Román, J. R., and Cantón, Y.: Effects of biocrust on soil erosio., and organic carbon losses under natural rainfall, Catena, 148, 117-125, https://doi.org/10.1016/j.catena.2016.06.017, 2017.

Concostrina-Zubiri, L., Martínez, I., Rabasa, S. G., and Escudero, A.: The influence of environmental factors on biological soil crust: From a community perspective to a species level approach, J. Veg. Sci., 25, 503-513, https://doi.org/10.1111/jvs.12084, 2014a.

Concostrina-Zubiri, L., Pescador, D. S., Martínez, I., and Escudero, A.: Climat, and small scale factors determine functional diversity shifts of biological soil crusts in Iberian drylands, Biodivers. Conserv., 23, 1757-1770, https://doi.org/10.1007/s10531-0140683-9, 2014b.

Concostrina-Zubiri, L., Molla, I., Velizarova, E., and Branquinho, C.: Grazing or Not Grazing: Implications for Ecosystem Services Provided by Biocrusts in Mediterranean Cork Oak Woodlands, L. Degrad. Dev., 28, 1345-1353, https://doi.org/10.1002/ldr.2573, 2017.

Concostrina-Zubiri, L., Martínez, I., and Escudero, A.: Lichen-biocrust diversity in a fragmented dryland: Fine scale factors are better predictors than landscape structure, Sci. Total Environ., 628-629, 882-892, https://doi.org/10.1016/j.scitotenv.2018.02.090, 2018.

Concostrina-Zubiri, L., Arenas, J. M., Martínez, I., and Escudero, A.: Unassisted establishment of biological soil crusts on dryland road slopes, Web Ecol., 19, 39-51, https://doi.org/10.5194/we19-39-2019, 2019.

Cortina, J., Martín, N., Maestre, F. T., and Bautista, S.: Disturbance of the biological soil crust., and performance of Stipa tenacissima in a semi-arid Mediterranean steppe, Plant Soil, 334, 311-322, https://doi.org/10.1007/s11104-010-0384-4, 2010.

Crespo, A.: Composición florística de la costra de líquenes del Herniario-Teucrietum pumili de la provincia de Madrid, Anales del Instituto Botánico Antonio José = Cavanilles, 30, 57-68, 1973.

Crespo, A. and Barreno, E.: Ensayo florístico y ecológico de la vegetación liquénica de los yesos del centro de España (Fulgensietalia desertori ord. nov), Anales del Instituto Botánico Cavanilles, 32, 873-908, 1975.

Delgado-Baquerizo, M., Castillo-Monroy, A. P., Maestre, F. T., and Gallardo, A.: Plant., and biological soil crusts modulate the dominance of $\mathrm{N}$ forms in a semi-arid grassland, Soil Biol. Biochem. 42, 376-378, https://doi.org/10.1016/j.soilbio.2009.11.003, 2010.

Delgado-Baquerizo, M., Covelo, F., Maestre, F. T., and Gallardo, A.: Biological soil crusts affect small-scale spatial patterns of inorganic $\mathrm{N}$ in a semiarid Mediter- 
ranean grassland, J. Arid Environ., 91, 147-150, https://doi.org/10.1016/j.jaridenv.2013.01.005, 2013a.

Delgado-Baquerizo, M., Maestre, F. T., and Gallardo, A.: Biological soil crusts increase the resistance of soil nitrogen dynamics to changes in temperatures in a semi-arid ecosystem, Plant Soil, 366, 35-47, https://doi.org/10.1007/s11104-012-1404-3, 2013b.

Delgado-Baquerizo, M., Maestre, F. T., Rodríguez, J. G. P., and Gallardo, A.: Biological soil crusts promote $\mathrm{N}$ accumulation in response to dew events in dryland soils, Soil Biol. Biochem., 62, 22-27, https://doi.org/10.1016/j.soilbio.2013.02.015, 2013c.

Delgado-Baquerizo, M., Maestre, F. T., Eldridge, D. J., Bowker, M. A., Ochoa, V., Gozalo, B., Berdugo, M., Val, J., and Singh, B. K.: Biocrust-forming mosses mitigate the negative impacts of increasing aridity on ecosystem multifunctionality in drylands, New Phytol., 209, 1540-1552, https://doi.org/10.1111/nph.13688, 2016.

Díaz, S., Demissew, S., Carabias, J., Joly, C., Lonsdale, M., Ash, N., Larigauderie, A., Adhikari, J. R., Arico, S., Báldi, A., Bartuska, A., Baste, I. A., Bilgin, A., Brondizio, E., Chan, K. M. A., Figueroa, V. E., Duraiappah, A., Fischer, M., Hill, R., Koetz, T., Leadley, P., Lyver, P., Mace, G. M., Martin-Lopez, B., Okumura, M., Pacheco, D., Pascual, U., Pérez, E. S., Reyers, B., Roth, E., Saito, O., Scholes, R. J., Sharma, N., Tallis, H., Thaman, R., Watson, R., Yahara, T., Hamid, Z. A., Akosim, C., Al-Hafedh, Y., Allahverdiyev, R., Amankwah, E., Asah, T. S., Asfaw, Z., Bartus, G., Brooks, A. L., Caillaux, J., Dalle, G., Darnaedi, D., Driver, A., Erpul, G., Escobar-Eyzaguirre, P., Failler, P., Fouda, A. M. M., Fu, B., Gundimeda, H., Hashimoto, S., Homer, F., Lavorel, S., Lichtenstein, G., Mala, W. A., Mandivenyi, W., Matczak, P., Mbizvo, C., Mehrdadi, M., Metzger, J. P., Mikissa, J. B., Moller, H., Mooney, H. A., Mumby, P., Nagendra, H., Nesshover, C., Oteng-Yeboah, A. A., Pataki, G., Roué, M., Rubis, J., Schultz, M., Smith, P., Sumaila, R., Takeuchi, K., Thomas, S., Verma, M., Yeo-Chang, Y., and Zlatanova, D.: The IPBES Conceptual Framework - connecting natur., and people, Curr. Opin. Environ. Sustain., 14, 1-16, https://doi.org/10.1016/j.cosust.2014.11.002, 2015.

Eldridge, D. J., Bowker, M. A., Maestre, F. T., Alonso, P., Mau, R. L., Papadopoulos, J., and Escudero, A.: Interactive effects of three ecosystem engineers on infiltration in a semi-arid Mediterranean grassland, Ecosystems, 13, 499-510, https://doi.org/10.1007/s10021-010-9335-4, 2010.

Ellison, A.: It's time to get real about conservation, Nature, 538, https://doi.org/10.1038/538141a, 2016.

Escolar, C., Martínez, I., Bowker, M. A., and Maestre, F. T.: Warming reduces the growt., and diversity of biological soil crusts in a semi-arid environment: Implications for ecosystem structur., and functioning, Philos. Trans. R. Soc. B Biol. Sci., 367, 3087-3099, https://doi.org/10.1098/rstb.2011.0344, 2012.

Escolar, C., Maestre, F. T., and Rey, A.: Biocrusts modulate warming, and rainfall exclusion effects on soil respiration in a semi-arid grassland, Soil Biol. Biochem., 80, 9-17, https://doi.org/10.1016/j.soilbio.2014.09.019, 2015.

Escudero, A., Martínez, I., de la Cruz, A., Otálora, M. A. G., and Maestre, F. T.: Soil lichens have speciesspecific effects on the seedling emergence of three gypsophile plant species, J. Arid Environ., 70, 18-28, https://doi.org/10.1016/j.jaridenv.2006.12.019, 2007.
García-Palacios, P., Bowker, M. A., Maestre, F. T., Soliveres, S., Valladares, F., Papadopoulos, J., and Escudero, A.: Ecosystem development in roadside grasslands: Biotic control, plant-soil interactions, and dispersal limitations, Ecol. Appl., 21, 2806-2821, https://doi.org/10.1890/11-0204.1, 2011.

Gotelli, N. J., Ulrich, W., and Maestre, F. T.: Randomization tests for quantifying species importance to ecosystem function, Methods Ecol. Evol., 2, 634-642, https://doi.org/10.1111/j.2041210X.2011.00121.x, 2011.

Guerra, J., Ros, R. M., Cano, M. J., and Casares, M.: Gypsiferous outcrops in SE Spain, refuges of rare, vulnerabl., and endangered bryophyte, and lichens, Cryptogamie, Bryologie et Lichènologie, 16, 125-135, 1995.

IPCC (Intergovernmental Panel on Climate Change): Climate Change 2013, The Physical Science Basis. Working Group I Contribution to the Fifth Assessment Report of the Intergovernmental Panel on Climate Change, 2013.

Kadykalo, A. N., López-Rodriguez, M. D., Ainscough, J., Droste, N., Ryu, H., Ávila-Flores, G., Le Clec'h, S., Muñoz, M. C., Nilsson, L., Rana, S., Sarkar, P., Sevecke, K. J., and Harmáčková, Z. V.: Disentangling "ecosystem services", and "nature's contributions to people", Ecosyst. People, 15, 269-287, https://doi.org/10.1080/26395916.2019.1669713, 2019.

Ladrón de Guevara, M., Lázaro, R., Quero, J. L., Ochoa, V., Gozalo, B., Berdugo, M., Uclés, O., Escolar, C., and Maestre, F. T.: Simulated climate change reduced the capacity of lichendominated biocrusts to act as carbon sinks in two semi-arid Mediterranean ecosystems, Biodivers. Conserv., 23, 1787-1807, https://doi.org/10.1007/s10531-014-0681-y, 2014.

Ladrón De Guevara, M., Lázaro, R., Quero, J. L., Chamizo, S., and Domingo, F.: Easy-to-make portable chamber for in situ $\mathrm{CO}_{2}$ exchange measurements on biological soil crusts, Photosynthetica, 53, 72-84, https://doi.org/10.1007/s11099-015-0086-5, 2015.

Lafuente, A., Berdugo, M., Ladrón de Guevara, M., Gozalo, B., and Maestre, F. T.: Simulated climate change affects how biocrusts modulate water gain., and desiccation dynamics after rainfall events, Ecohydrology, 11, 1-10, https://doi.org/10.1002/eco.1935, 2018.

Lázaro, R., Cantón, Y., Solé-Benet, A., Bevan, J., Alexander, R., Sancho, L. G., and Puigdefábregas, J.: The influence of competition between lichen colonizatio., and erosion on the evolution of soil surfaces in the Tabernas badlands (SE Spain., and its landscape effects, Geomorphology, 102, 252-266, https://doi.org/10.1016/j.geomorph.2008.05.005, 2008.

Llimona, X.: Las comunidades de líquenes de los yesos de España, Universidad de Barcelona, Secretariado de Publicaciones, Barcelona, 1974.

Lorite, J., Agea, D., García-Robles, H., Cañadas, E. M., Rams, S., and Sánchez-Castillo, P.: Plant recovery techniques do not ensure biological soil-crust recovery after gypsum quarrying: a call for active restoration, Restor. Ecol., 1-10, https://doi.org/10.1111/rec.13059, 2019.

Luzuriaga, A. L., Sánchez, A. M., Maestre, F. T., and Escudero, A.: Assemblage of a semi-arid annual plant community: Abioti, and biotic filters act hierarchically, PLoS One, 7, 1-9, https://doi.org/10.1371/journal.pone.0041270, 2012.

Mace, G. M.: Whose conservation?, Science, 345, 1558-1560, https://doi.org/10.1126/science.1254704, 2014. 
Maestre, F. T.: Small-scale spatial patterns of two soil lichens in semi-arid Mediterranean steppe, Lichenologist, 35, 71-81, https://doi.org/10.1006/lich.2002.0425, 2003a.

Maestre, F. T.: Variaciones en el patrón espacial a pequeña escala de los componentes de la costra biológica en un ecosistema Mediterráneo semiárido, Rev. Chil. Hist. Nat., 76, 35-46, https://doi.org/10.4067/s0716-078x2003000100004, 2003b.

Maestre, F. T. and Cortina, J.: Spatial patterns of surface soil properties and vegetation in a Mediterranean semi-arid steppe, Plant Soil, 241, 279-291, https://doi.org/10.1023/A:1016172308462, 2002.

Maestre, F. T. and Cortina, J.: Small-scale spatial variation in soil $\mathrm{CO}_{2}$ efflux in a Mediterranean semiarid steppe, Appl. Soil Ecol., 23, 199-209, https://doi.org/10.1016/S0929-139300050-7, 2003.

Maestre, F. T., Escudero A., Martinez, I., Guerrero, C., and Rubio, A.: Does spatial pattern matter to ecosystem functioning? Insights from biological soil crusts, Funct. Ecol., 19, 566-573, https://doi.org/10.1111/j.1365-2435.2005.01000.x, 2005.

Maestre, F. T., Escolar, C., Martínez, I., and Escudero, A.: Are soil lichen communities structured by biotic interactions? A null model analysis, J. Veg. Sci., 19, 261-266, https://doi.org/10.3170/2007-8-18366, 2008.

Maestre, F. T., Martínez, I., Escolar, C., and Escudero, A.: On the relationship between abiotic stres., and co-occurrence patterns: An assessment at the community level using soil lichen communitie, and multiple stress gradients, Oikos, 118, 1015-1022, https://doi.org/10.1111/j.1600-0706.2009.17362.x, 2009.

Maestre, F. T., Bowker, M. A., Escolar, C., Puche, M. D., Soliveres, S., Maltez-Mouro, S., García-Palacios, P., CastilloMonroy, A. P., Martínez, I., and Escudero, A.: Do biotic interactions modulate ecosystem functioning along stress gradients? Insights from semi-arid plant and biological soil crust communities, Philos. Trans. R. Soc. B Biol. Sci., 365, 2057-2070, https://doi.org/10.1098/rstb.2010.0016, 2010.

Maestre, F. T., Bowker, M. A., Cantón, Y., Castillo-Monroy, A. P., Cortina, J., Escolar, C., Escudero, A., Lázaro, R., and Martínez, I.: Ecolog., and functional roles of biological soil crusts in semiarid ecosystems of Spain, J. Arid Environ., 75, 1282-1291, https://doi.org/10.1016/j.jaridenv.2010.12.008, 2011.

Maestre, F. T., Escolar, C., de Guevara, M. L., Quero, J. L., Lázaro, R., Delgado-Baquerizo, M., Ochoa, V., Berdugo, M., Gozalo, B., and Gallardo, A.: Changes in biocrust cover drive carbon cycle responses to climate change in drylands, Glob. Chang. Biol., 19, 3835-3847, https://doi.org/10.1111/gcb.12306, 2013.

Maier, S., Schmidt, T. S. B., Zheng, L., Peer, T., Wagner, V., and Grube, M.: Analyses of dryland biological soil crusts highlight lichens as an important regulator of microbial communities, Biodivers. Conserv., 23, 1735-1755, https://doi.org/10.1007/s10531-014-0719-1, 2014.

Maier, S., Tamm, A., Wu, D., Caesar, J., Grube, M., and Weber, B.: Photoautotrophic organisms control microbial abundance, diversity., and physiology in different types of biological soil crusts, ISME J., 12, 1032-1046, https://doi.org/10.1038/s41396018-0062-8, 2018.

Martínez, I., Escudero, A., Maestre, F. T., De La Cruz, A., Guerrero, C., and Rubio, A.: Small-scale patterns of abundance of mosse., and lichens forming biological soil crusts in two semi-arid gypsum environments, Aust. J. Bot., 54, 339-348, https://doi.org/10.1071/BT05078, 2006.
Martínez-Valderrama, J., Ibáñez, J., Alcalá, F., and Martínez, S.: SAT: A Software for Assessing the Risk of Desertification in Spain, Sci. Program., 2020, 7563928, https://doi.org/10.1155/2020/7563928, 2020.

Mastrángelo, M. E., Pérez-Harguindeguy, N., Enrico, L., Bennett, E., Lavorel, S., Cumming, G. S., Abeygunawardane, D., Amarilla, L. D., Burkhard, B., Egoh, B. N., Frishkoff, L., Galetto, L., Huber, S., Karp, D. S., Ke, A., Kowaljow, E., KronenburgGarcía, A., Locatelli, B., Martín-López, B., Meyfroidt, P., Mwampamba, T. H., Nel, J., Nicholas, K. A., Nicholson, C., Oteros-Rozas, E., Rahlao, S. J., Raudsepp-Hearne, C., Ricketts, T., Shrestha, U. B., Torres, C., Winkler, K. J., and Zoeller, K.: Key knowledge gaps to achieve global sustainability goals, Nat. Sustain., 2, 1115-1121, https://doi.org/10.1038/s41893019-0412-1, 2019.

Mendoza-Aguilar, D. O., Cortina, J., and Pando-Moreno, M.: Biological soil crust influence on germinatio., and rooting of two key species in a Stipa tenacissima steppe, Plant Soil, 375, 267-274, https://doi.org/10.1007/s11104-013-1958-8, 2014.

Miralles-Mellado, I., Cantón, Y., and Solé-Benet, A.: TwoDimensional Porosity of Crusted Silty Soils: Indicators of Soil Quality in Semiarid Rangelands?, Soil Sci. Soc. Am. J., 75, 1330-1342, https://doi.org/10.2136/sssaj2010.0283, 2011.

Miralles, I., van Wesemael, B., Cantón, Y., Chamizo, S., Ortega, R., Domingo, F., and Almendros, G.: Surrogate descriptors of C-storage processes on crusted semiarid ecosystems, Geoderma, 189-190, 227-235, https://doi.org/10.1016/j.geoderma.2012.05.011, 2012a.

Miralles, I., Domingo, F., Cantón, Y., Trasar-Cepeda, C., Leirós, M. C., and Gil-Sotres, F.: Hydrolase enzyme activities in a successional gradient of biological soil crusts in ari., and semi-arid zones, Soil Biol. Biochem., 53, 124-132, https://doi.org/10.1016/j.soilbio.2012.05.016, 2012b.

Miralles, I., Domingo, F., García-Campos, E., Trasar-Cepeda, C., Leirós, M. C., and Gil-Sotres, F.: Biologica, and microbial activity in biological soil crusts from the Tabernas desert, a sub-arid zone in SE Spain, Soil Biol. Biochem., 55, 113-121, https://doi.org/10.1016/j.soilbio.2012.06.017, 2012c.

Miralles, I., Trasar-Cepeda, C., Leirós, M. C., and GilSotres, F.: Labile carbon in biological soil crusts in the Tabernas desert, SE Spain, Soil Biol. Biochem., 58, 1-8, https://doi.org/10.1016/j.soilbio.2012.11.010, 2013.

Miralles, I., Trasar-Cepeda, C., Leirós, M. C., Barbosa-Pereira, L., and Gil-Sotres, F.: Capacity of biological soil crusts colonized by the lichen Diploschistes to metabolize simple phenols, Plant Soil, 385, 229-240, https://doi.org/10.1007/s11104-014-2220-8, 2014.

Miralles, I., Ladrón de Guevara, M., Chamizo, S., RodríguezCaballero, E., Ortega, R., van Wesemael, B., and Cantón, Y.: Soil $\mathrm{CO}_{2}$ exchange controlled by the interaction of biocrust successional stag., and environmental variables in two semiarid ecosystems, Soil Biol. Biochem., 124, 11-23, https://doi.org/10.1016/j.soilbio.2018.05.020, 2018.

Ochoa-Hueso, R. and Manrique, E.: Effects of nitrogen depositio., and soil fertility on cove, and physiology of Cladonia foliacea (Huds.) Willd., a lichen of biological soil crusts from Mediterranean Spain, Environ. Pollut., 159, 449-457, https://doi.org/10.1016/j.envpol.2010.10.021, 2011. 
Ochoa-Hueso, R., Hernandez, R. R., Pueyo, J. J., and Manrique, E.: Spatial distribution, and physiology of biological soil crusts from semi-arid central Spain are related to soil chemistr., and shrub cover, Soil Biol. Biochem., 43, 1894-1901, https://doi.org/10.1016/j.soilbio.2011.05.010, 2011.

Ochoa-Hueso, R., Delgado-Baquerizo, M., Gallardo, A., Bowker, M. A., and Maestre, F. T.: Climatic conditions, soil fertility, and atmospheric nitrogen deposition largely determine the structure, and functioning of microbial communities in biocrustdominated Mediterranean drylands, Plant Soil, 399, 271-282, https://doi.org/10.1007/s11104-015-2695-y, 2016.

Ochoa-Hueso, R., Mondragon-Cortés, T., Concostrina-Zubiri, L., Serrano-Grijalva, L., and Estébanez, B.: Nitrogen deposition reduces the cover of biocrust-forming lichen., and soil pigment content in a semiarid Mediterranean shrubland, Environ. Sci. Pollut. Res., 24, 26172-26184, https://doi.org/10.1007/s11356017-0482-4, 2017.

Pintado, A., Sancho, L. G., Green, T. G. A., Blanquer, J. M., and Lázaro, R.: Functional ecology of the biological soil crust in semiarid SE Spain: Su., and shade populations of Diploschistes diacapsis (Ach.) Lumbsch, Lichenologist, 37, 425432, https://doi.org/10.1017/S0024282905015021, 2005.

Raggio, J., Pintado, A., Vivas, M., Sancho, L. G., Büdel, B., Colesie, C., Weber, B., Schroeter, B., Lázaro, R., and Green, T. G. A.: Continuous chlorophyll fluorescence, gas exchange, and microclimate monitoring in a natural soil crust habitat in Tabernas badlands, Almería, Spain: Progressing towards a model to understand productivity, Biodivers. Conserv., 23, 1809-1826, https://doi.org/10.1007/s10531-014-0692-8, 2014.

Raggio, J., Allan Green, T. G., Sancho, L. G., Pintado, A., Colesie, C., Weber, B., and Büdel, B.: Metabolic activity duration can be effectively predicted from macroclimatic data for biological soil crust habitats across Europe, Geoderma, 306, 10-17, https://doi.org/10.1016/j.geoderma.2017.07.001, 2017.

Reed, S. C., Delgado-Baquerizo, M., and Ferrenberg, S.: Biocrust scienc., and global change, New Phytol., 223, 1047-1051, https://doi.org/10.1111/nph.15992, 2019.

Rey, A., Oyonarte, C., Morán-López, T., Raimundo, J., and Pegoraro, E.: Changes in soil moisture predict soil carbon losses upon rewetting in a perennial semiarid steppe in SE Spain, Geoderma, 287, 135-146, https://doi.org/10.1016/j.geoderma.2016.06.025, 2017.

Rodríguez-Caballero, E., Cantón, Y., Chamizo, S., Afana, A., and Solé-Benet, A.: Effects of biological soil crusts on surface roughness and implications for runof., and erosion, Geomorphology, 145-146, 81-89, https://doi.org/10.1016/j.geomorph.2011.12.042, 2012.

Rodríguez-Caballero, E., Cantón, Y., Chamizo, S., Lázaro, R. and Escudero, A.: Soil Loss, and Runoff in Semiarid Ecosystems: A Complex Interaction Between Biological Soil Crusts, Microtopography, and Hydrological Drivers, Ecosystems, 16, 529546, https://doi.org/10.1007/s10021-012-9626-z, 2013.

Rodríguez-Caballero, E., Cantón, Y., Lazaro, R., and Solé-Benet, A.: Cross-scale interactions between surface component., and rainfall properties. Non-linearities in the hydrologica., and erosive behavior of semiarid catchments, J. Hydrol., 517, 815-825, https://doi.org/10.1016/j.jhydrol.2014.06.018, 2014a.

Rodríguez-Caballero, E., Escribano, P., and Cantón, Y.: Advanced image processing methods as a tool to ma., and quantify different types of biological soil crust, ISPRS J. Photogramm. Remote Sens., 90, 59-67, https://doi.org/10.1016/j.isprsjprs.2014.02.002, 2014b.

Rodríguez-Caballero, E., Aguilar, M. Á., Castilla, Y. C., Chamizo, S., and Aguilar, F. J.: Swelling of biocrusts upon wetting induces changes in surface micro-topography, Soil Biol. Biochem., 82, 107-111, https://doi.org/10.1016/j.soilbio.2014.12.010, 2015a.

Rodríguez-Caballero, E., Cantón, Y., and Jetten, V.: Biological soil crust effects must be included to accurately model infiltratio., and erosion in drylands: An example from Tabernas Badlands, Geomorphology, 241, 331-342, https://doi.org/10.1016/j.geomorph.2015.03.042, 2015b.

Rodríguez-Caballero, E., Escribano, P., Olehowski, C., Chamizo, S., Hill, J., Cantón, Y., and Weber, B.: Transferability of multi., and hyperspectral optical biocrust indices, ISPRS J. Photogramm. Remote Sens., 126, 94-107, https://doi.org/10.1016/j.isprsjprs.2017.02.007, 2017.

Rodriguez-Caballero, E., Belnap, J., Büdel, B., Crutzen, P. J., Andreae, M. O., Pöschl, U., and Weber, B.: Dryland photoautotrophic soil surface communities endangered by global change, Nat. Geosci., 11, 185-189, https://doi.org/10.1038/s41561-0180072-1, 2018a.

Rodríguez-Caballero, E., Chamizo, S., Roncero-Ramos, B., Román, R., and Cantón, Y.: Runoff from biocrust: A vital resource for vegetation performance on Mediterranean steppes, Ecohydrology, 11, 1-13, https://doi.org/10.1002/eco.1977, 2018b.

Rodríguez-Caballero, E., Castro, A. J., Chamizo, S., QuintasSoriano, C., Garcia-Llorente, M., Cantón, Y., and Weber, B.: Ecosystem services provided by biocrusts: From ecosystem functions to social values, J. Arid Environ., 159, 45-53, https://doi.org/10.1016/j.jaridenv.2017.09.005, 2018c.

Rodríguez-Caballero, E., Román, J. R., Chamizo, S., Roncero Ramos, B., and Cantón, Y.: Biocrust landscape-scale spatial distribution is strongly controlled by terrain attributes: Topographic thresholds for colonization in a semiarid badland system, Earth Surf. Process. Land., 44, 2771-2779, https://doi.org/10.1002/esp.4706, 2019.

Román, J. R., Roncero-Ramos, B., Chamizo, S., RodriguezCaballero, E., and Canton, Y.: Restoring soil functions by means of cyanobacteria inoculation: Importance of soil conditions and species selection, Land Degrad. Dev., 28, 31840-3193, 2018.

Román, J. R., Rodríguez-Caballero, E., Rodríguez-Lozano, B., Roncero-Ramos, B., Chamizo, S., Águila-Carricondo, P., and Cantón, Y.: Spectral response analysis: An indirec., and non-destructive methodology for the chlorophyll quantification of biocrusts, Remote Sens., 11, 1350, https://doi.org/10.3390/rs11111350, 2019.

Roncero-Ramos, B., Román, J. R., Gómez-Serrano, C., Cantón, Y., and Acién, F. G.: Production of a biocrust-cyanobacteria strain (Nostoc commune) for large-scale restoration of dryland soils, J. Appl. Phycol., 31, 2217-2230, https://doi.org/10.1007/s10811019-1749-6, 2019a.

Roncero-Ramos, B., Muñoz-Martín, M. Á., Chamizo, S., Fernández-Valbuena, L., Mendoza, D., Perona, E., Cantón, Y., and Mateo, P.: Polyphasic evaluation of key cyanobacteria in biocrusts from the most arid region in Europe, PeerJ, 2019, 1-27, https://doi.org/10.7717/peerj.6169, 2019b.

Souza-Egipsy, V., Wierzchos, J., Sancho, C., Belmonte, A., and Ascaso, C.: Role of biological soil crust cover in bioweatherin, and 
protection of sandstones in a semi-arid landscape (Torrollones de Gabarda, Huesca, Spain), Earth Surf. Process. Land., 29, 16511661, https://doi.org/10.1002/esp.1118, 2004.

Uclés, O., Villagarcía, L., Cantón, Y., and Domingo, F.: Partitioning of non rainfall water input regulated by soil cover type, Catena, 139, 265-270, https://doi.org/10.1016/j.catena.2015.02.018, 2016.

Weber, B., Büdel, B., and Belnap, J.: Biological Soil Crusts as an Organizing Principle in Drylands, Ecological Studies, vol. 226, Springer International Publishing, 2016.

Williams, L., Loewen-Schneider, K., Maier, S., and Büdel, B.: Cyanobacterial diversity of western European biological soil crusts along a latitudinal gradient, FEMS Microbiol. Ecol., 92, 1-9, https://doi.org/10.1093/femsec/fiw157, 2016.
Williams, L., Colesie, C., Ullmann, A., Westberg, M., Wedin, M., and Büdel, B.: Lichen acclimation to changing environments: Photobiont switching vs. climate-specific uniqueness in Psora decipiens, Ecol. Evol., 7, 2560-2574, https://doi.org/10.1002/ece3.2809, 2017.

Williams, L., Jung, P., Zheng, L. J., Maier, S., Peer, T., Grube, M., Weber, B., and Büdel, B.: Assessing recovery of biological soil crusts across a latitudinal gradient in Western Europe, Restor. Ecol., 26, 543-554, https://doi.org/10.1111/rec.12579, 2018. 